\title{
E-learning Spaces to Empower Students Collaborative Work Serving Individual Goals
}

\author{
Bálint Nagy, Mariann Váraljai, Anita Mihalovicsné Kollár \\ University of Dunaújváros, Táncsics M. u. 1/A, H-2400 Dunaújváros Hungary, \\ nagyb@uniduna.hu,varaljai@uniduna.hu,mkollar@uniduna.hu
}

\begin{abstract}
Innovation has an impact on modern society, so it appears as a demand of the learning society in the educational process. However, there are many other factors that need to be taken into account in supporting an individual's success in designing and implementing a learning process, not just technological change. As opportunities are multiplied, technological support for collaborative work is becoming increasingly demanding to effectively utilize these opportunities in everyday student work. The aim of higher education is to support student success. The continuous adaptation of educational environment to student needs is an important element of this need.
\end{abstract}

\section{Strategic Educational Aspirations of Hungary in the Spirit of Innovation}

Internationally, the $\mathrm{OECD}^{1}$ prepared and published a study in 2010 , "The Nature of Learning: Using Research to Inspire Practice", which contains the basic principles of the learning environment specifically in the educational sense. [1]

The principles emphasize the personal, inclusive and community nature of the environment to be established, as well as its learner-centered and structured nature. Based on these principles, Hungary released its Digital Education Strategy. According to the Digital Education Strategy issued in the Digital Welfare Program framework in Hungary, in line with the strategy of "Change in Higher Education," Hungarian higher education develops a uniform online digital environment which offers personalized learning opportunities, tailored to individuals interests and life situations. An online learning space was established and also a learning community where community members are supported in their lifelong learning and self-development." [2]

\footnotetext{
${ }^{1} \mathrm{OECD}=$ Organisation for Economic Co-operation and Development
} 
While "The vision of public education concerns a high-quality and equitable public education system that prepares young people -who would be capable of adapting to the social and economic spheres of Europe and the world- for the labor market, higher education, and lifelong learning." As an intervention area, the government indicated that "information retrieval, processing, the use of collaborative ICT-supported solutions and media awareness should be built into students' learning tasks. The practical application of ICT should be embedded in the acquisition of science subjects through digital sensor-based measurement, data processing, evaluation and visualization (such as 3D printing)." [2]

The role of higher education in the high-level training of future generations is crucial. With the use of tools and methods that support training, the institutions strive to change in line with the results of scientific research and development to adapt to the process of innovation.

\section{Higher Education Efforts to Support the Goals of Educational Strategy}

In the field of higher education, there is a strong desire to create a learning environment that is tailored to student needs. This process is permanent and the environment itself is dynamically changing through the use of disruptive ${ }^{2}$ technologies. Student needs show a high degree of technological commitment. This characteristic is mainly manifested in the definition of the way of searching/gathering, processing information and content-generating. A common feature of the learning community is that they are extremely adaptable to innovation trends, able to immediately adopt and use emerging technologies, wellcome their disruptive feature. They are technologically committed, instant feedback is important during their work, and they prefer short text and large amounts of audio-visual content. [3] They like to work in teams, have a strong sense of community. The sense of belonging to the community enhances the sense of self-confidence as they enjoy the support of the community. [4]

The digital education strategy defines the educational environment in several aspects. In this study, we examined online collaboration from the many aspects and examined its significance at the University of Dunaújváros.

${ }^{2}$ disruptive $=$ "creative destruction" 


\subsection{Former Research Results in Serve of Further Development}

In our previous study, which focused on the relationship between the individual and the community, we explored the necessity of expanding the learning space from this aspect. Based on the results, it can be stated that students are very keen on existing in the online environment during their learning process, regardless of the type and form of work they do. To achieve a more nuanced picture, further research shows that an e-learning environment (e.g. the Moodle) is more suitable for student-teacher communication (and of course cooperation) rather than peerto-peer communication. It is also true that communication with peers is more likely to take place in an online environment (e.g. Facebook group) than face to face. Observation of student activities leads to the conclusion that the individual requires collaboration with peers, but the ability to collaborate if they have an educational goal that is strongly influenced by the nature of a certain subject.

In this study, we focused on student activities in subjects requiring different forms of work, with a particular focus on learning activities in the online environment. Determining the conclusions of the study, student effectiveness played the main role.

\subsection{Innovative Tools and Methods}

The use of innovative tools and methods actively contributes to the success of the learning process. Supporting, developing, extending all of these into the virtual learning environment is an important factor in the teaching process. In order to support student success in higher education, various disruptive innovative technologies and pedagogical methods are used to obtain and process information and generate knowledge.

In the system of efficiency, effectiveness, and success in the field of education, the development of a learning environment plays just as important role as the appropriate method of teaching, the way in which learning is organized and supported or the strategy. [5] [6] Many previous research have dealt with studying the learning environment, developing innovative learning environments to make learning effective. [7] [8] [9] [10] [11]

The technological changes that spill over into the field of education are creating the conditions in which the "creative destruction" is finding its way. Typically, the result of this process is a change in the technology of education, in line with modernization, the incorporation of new technologies and methods into the educational process. Innovative methods that break with traditional, wellestablished practices and use modern tools can stimulate participants in the education process, thus facilitating the accumulation of human capital, ie abilities and skills. [12] [13] 


\subsection{Applied Forms of Work in an Effective Learning Environment}

This study presents the results of our research on learning organization, focusing on different forms of work, in order to make learning successful. One of the most significant features of constructivist pedagogy is effective learning organizing method. The modern ICT and CogInfoCom supported education [14] [38] has several additional benefits and possibilities to improve the learning effectiveness like Virtual Reality-based learning spaces [15, 16, 17] and virtual labs [18], serious games, gamification or team-based collaborative education [19], [20], Human-Computer Interfaces [21, 22, 23] and other educational environments [24, $25,26,27]$.

In traditional "frontal" classwork, the teacher is an active source of knowledge and the student is a passive learner with very little interaction. In contrast, to this, in an effective learning environment, classical transferring and receiving roles cease, the student becomes active, the amount of interaction increases, and the student can now be a source of information and knowledge transfer. In this learning environment, students can collaborate with one another in a variety of forms of work and help each other with their work through a variety of methods and tools.

However, when choosing the form of work to be used, the particular educational objective must be taken into account, since each form of work has different advantages and disadvantages and promotes the development of different fields.

One type of traditional mode is frontal classwork, which has the advantage that an information source can transmit information to a large mass of people at the same time and in one place. Teacher explanation thus facilitates understanding, develops attention and concentration. Typically, it is well suited for communicating new knowledge, general definitions, regularities, and facts. Of course, this form of work can be effectively transposed into an innovative learning environment through video conferencing, webcasting, or even virtual lectures. The space in this sense is the electronic environment, the virtual space.

Another form of a traditional learning organization is individual student work. It has the advantage of allowing a better and deeper understanding of the trainee's individual qualities and allows for individual treatment, as well as enhances the ability to highlight and develop autonomy. [28]

Effective learning methods include pair work, teamwork (which can be a task solution or experiment) and teamwork around project tasks. The advantage of each form of work is that it encourages cooperation, improves helpfulness, tolerance and conflict management. However, debates and the possibility of division of tasks can turn the advantage into a disadvantage, debates can escalate because students are unable to work properly and reach consensus, attention can be misaligned, and responsibility can be weakened. [29] 
Still, there are many forms of work that help the student, including individual and teamwork. These are becoming more and more widespread, hence these two forms of work are at the heart of our investigation. According to scientific researches, one of the characteristic features of Generation Y, who is extremely committed to modern technology in higher education, is that they prefer teamwork and collaboration to work individually. [30]

\section{Aims and Methods of the Research}

In our research, the focus was on applicable forms of work in learning process to achieve success and quality.

We have chosen a popular form of empirical research, the questionnaire. According to the scientific approach, the student community serving as the core population of our study was a group of students with active student status in higher education who already fully "speak" the language of today's information society, so electronic questionnaires have proven to be the most appropriate means of interviewing.

The University of Dunaújváros is a modern technical university, which provides study programs taught in English language for international students from four continents. In the case of a project-based subject (Project Management and Practice) we have choosen the interview as a more direct method of questioning. In addition, foreign students fulfilled a self-reflection questionnaire at the end of the semester. Open-ended questions were applied during the interview face-toface and the electronic self-reflection questioning. We summarized the results of foreign students' questioning in a case study.

We used the random sampling method. The questionnaire was completed using the self-completion method, which has the great advantage that there is no questioner bias.

The numerical data of the received answers were processed with the Excel spreadsheet program of Microsoft Office suite. For open-ended questions, we conducted a content analysis.

Student activities were observed in four subjects (Informatics, Internet Technologies, Project Management and Practice and ERP Systems) that required the use of two different forms of work.

- The topics of Informatics and Internet Technologies are designed so that they allow individual student work, require autonomy and self-discipline, enable self-direction, rather than require cooperation or collaboration. 
- The curriculum of Project Management and Practice basically prefers teamwork as an applied method, as students work together in teams to design a long-term solution to a chosen task and to achieve a predefined goal according to a specific set of requirements.

- ERP Systems helps the practical application and acquisition of knowledge by carrying out a project assignment on the one hand and by completing a project task on the other.

\section{Results}

Our study focused on three areas: we drew conclusions by analysing basic statistics, device usage, and a questionnaire of teamwork.

\subsection{Questionnaire of Device Usage}

The first group of questions connected to general statistic information. In the summer of 2019, 58 students of the four subjects mentioned above were randomly interviewed. Given that three of the subjects are included in the curriculum of the IT profession where men are over represented, it is not surprising that they account for $70 \%$ of the respondents.

In the composition of the participants according to their study program, the highest proportion was Computer Science Engineering (43\%), one third Mechanical Engineering, 14\% Business Administration and Management students, other Communication and Media, Technical Management or Teacher of Engineering. Three-quarters of the sample student population takes part in bachelor, $20 \%$ in higher-level vocational training and only a small proportion studies on master level. Regarding the work schedule, the distribution has shifted to part-time students, with two- thirds of respondents attending part-time training and one-third attending full-time training. The answers of the first and secondyear students dominated, with $70 \%$ of the sample.

The second group of questions was connected to the use of devices. In this group of questions, we were curious as to know how typical is the innovative technologies in students' device usage, and how often they appear in their everyday lives, especially in their learning processes.

The digital world is already a natural medium for Generations $\mathrm{Y}$ and $\mathrm{Z}$ [32], so it is not surprising that almost all respondents have a computer or laptop (93\%). Nowadays, owning smartphones is also common in this age group, and this has returned in the answers, with $93 \%$ giving a positive answer. Nowadays, much fewer people own smart watches (19\%), video game consoles (29\%), drones (5\%), VR glasses ( $2 \%$, or 1 person). (Figure 1$)$ 


\section{Device supply}

I own this device I do not own this device but I have already used $=$ I do not have and have not used this device

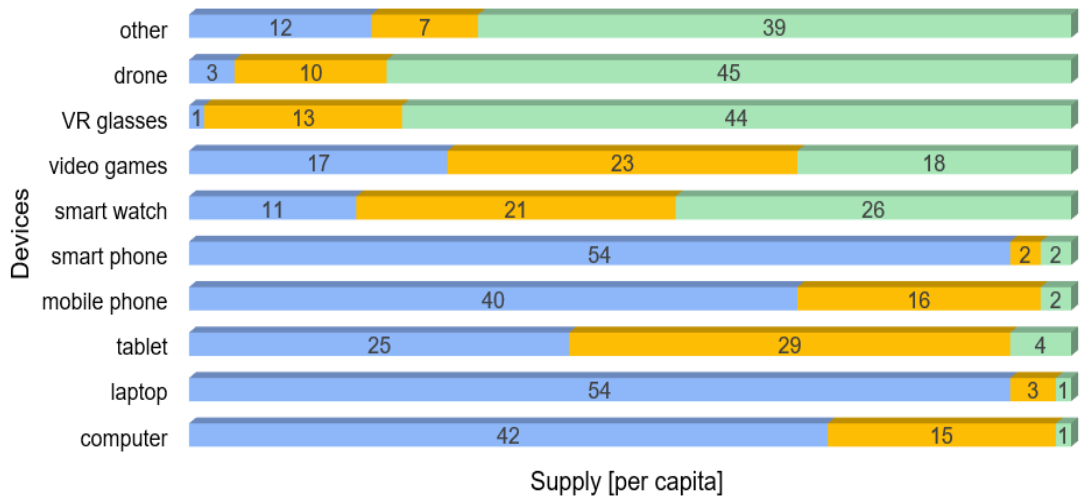

Figure 1

Innovative device supply (per capita)

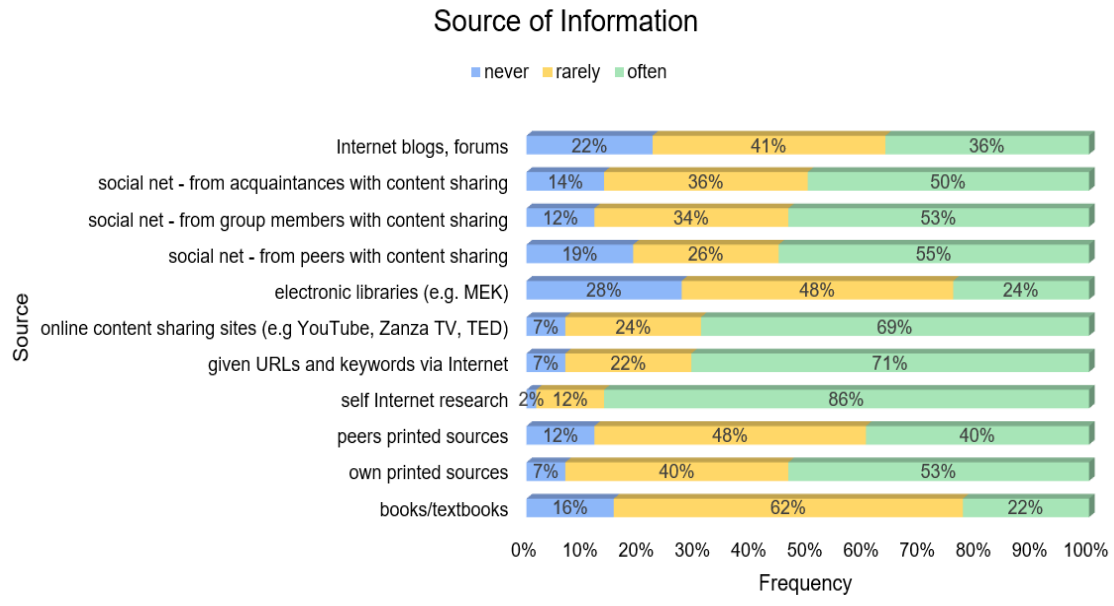

Figure 2

Source and frequency of information gathering

In this group of questions, we also examined where students learn about the curriculum and how they prepare for the examinations. The use of textbooks and electronic libraries is hardly typical (about 20-25\% of students chose the "often" option). According to half of the sample, printed notes owned by the students and social networking sites are used to obtain information. It shows that social media significantly determines the available knowledge and influences the students' relationships in the online space, and in an effective way facilitates learning by 
implementing cooperation. Slightly less is learned from blogs, forums, and peerreviewed notes $(35-40 \%)$. More popular are self-researched items (86\%) or URLs given by others $(71 \%)$, online content sharing sites $(69 \%)$, which indicates that they prefer using material on the World Wide Web to traditional books. (Figure 2)

The importance of digital curricula is also illustrated by the fact that while $60 \%$ have labeled textual content as the most typical source, $34 \%$ are already looking for video content.

\subsection{Questionnaire of Team Work}

The third group of questions is related to teamwork. With this set of questions, we sought to explore how students relate to two radically different forms of work. At the individual level, we were able to look at the issue from specific perspectives, where we first sought to find out how useful the teamwork approach was for the students to learn the subject matter. Another set of questions provided a more nuanced picture of the students' subjective opinions, their feelings about the forms of work, and their attitude towards collaboration.

Only $16 \%$ of the surveyed students indicated that they had not worked/studied in any form of collaborative work, so we can conclude that they usually have some experience with social work (i.e. team, group or pair work). The picture is further blurred by the fact that $59 \%$ of them have already taken part in teamwork, which is a higher level of collaboration, so their opinions are based on real experiences and are well-founded.

$78 \%$ of the sample included Informatics, $48 \%$ Project Management and Practice, $36 \%$ Internet Technologies and 19\% ERP systems. In the acquisition of Informatics, respondents rated the usefulness of teamwork on a scale of 1 to 5 on average as 3.1. Considering that there is only individual curriculum processing in this subject, it is thoughtful whether some common work might have to be introduced or modified in the future. In the case of Project Management and Practice, which prefers teamwork, the average of 4.1 also shows that the direction is right. In the case of Internet Technologies requiring autonomy, respondents also chose their current work format, with an average answer of 1.7. Also in the case of ERP Systems, where the application of self-learned curriculum in practice through collaboration should be synthesized, the 3.8 average of the answers does not justify any reconsideration yet. (Table 1)

Table 1

The importance of teamwork in different subjects

\begin{tabular}{|l|l|}
\hline Name of subject & Average of the usefulness of team work \\
\hline Informatics & 3.1 \\
\hline Project Management and Practice & 4.1 \\
\hline Internet Technologies & 1.7 \\
\hline ERP Systems & 3.8 \\
\hline
\end{tabular}




\subsection{A Case Study of a Team Work by Foreign Students in the University of Dunaújváros}

Project Management and Practice subject is also available for foreign students at the Universtiy of Dunaújváros (UOD) and moreover it is cumpulsory for students in the bachelor program of Computer Science Engineering. This case makes collaboration more exciting because of the varied national characteristics, linguistic diversity. The age match and the distance from their home points towards the frequent use of ICT devices and the permanent online exist.

In the case of foreign students, we applied face-to-face interviews and constant monitoring of the teamwork during the semester of Project Management and Practice subject. This period lasted 10 weeks with hard work during that time the team reached the top and delivered the finished product from an idea through initiation, planning, execution and closing under constant control. The team had to create several documents during the process: Initiation document, status reports, project software plan, final documentation, individual report (self-reflection), report of team work. Constant monitoring realized via electronic learning environment (Moodle) as assignments. The responsible person changed according to the certain task: each team member, team leader, a team member recommended by team leader, etc. Each monitoring checkpoint had a strict deadline so every team member were involved to work on their part of the project constantly. At the end of the semester as the closure of the project, the team presented their project process focusing the essential elements of project management: tasks, times, sources, costs. The results were displayed by MS Excel and MS Project charts, tables in MS PowerPoint presentation, the documentation and reports were created by MS Word saved as PDF.

\subsubsection{Students' Activities - at Once in Real World}

For the first time in the first lesson, every student gathered at the same place in the university, where they could get acquainted and the teacher could familiarize the project and the tasks to them. As the students had not met before and they just got a semester-long task to collaborate, they continued the meeting after the first lesson. They sat around a table of a cafe and discussed the first steps of managing a project.

Fortunately, they could pick a topic, that suited all the members of the team easily as it was a website development titled „The World” Restaurant Ordering Service. The project was about an online restaurant where people could browse the pages to select national dishes of different countries, which were to their liking. If they think they have chosen everything they want, they could make an order. The team had 6 members from different countries of the world. 
The team leader was selected based on their personal intuition of the first meeting. The most powerful, best speaker, and bravest student became the team leader who was willing to take the lead and overall responsibility.

During the first meeting, not only the task was selected, but roles were also assigned, taking into account the strengths of the members.

\subsubsection{Students' Activities - Online}

On this occasion, they also agreed that they would use the online environment to keep contact and share their ideas, documents, contents or ask for help.

- One of the most common social network (Facebook) turned out to be one of their choosen online enviromments. The messaging app and platform (Messenger) of this site was used for rapid message exchange as they could connect with each other instantly and constantly.

- Another website that provided them a quick and easy way to run their own team project was Google Site. This technology tool was useful for project management as it included the essential components: „Home” page: they could give basic information connected to the project (the name, its aim, etc.), „Project at a Glance”, „Project Objectives”, „To Dos”, „Calendar”, „Files and Project Documents”, „Project Discussion”, „Comments and Questions”. Every member could make record, set assignments, upload files and discuss what to do next, etc.

- The electronic learning environment of the university was useful for them to gain the relevant information for their teamwork, get the right help at the right time, and to be guided on the side.

To maximize efficiency, each task was assigned to someone who was routine in that area. The motivation of the team also contributed to the success. The team leader reported regularly to participants so he was always aware of the pace of progress and was able to reallocate resources immediately when someone needed help.

\subsubsection{Device Usage and Teamwork from the Aspect of Communication}

Communication is one of the main cornerstones and components of teamwork.

- Several channels were used for communication between members: in addition to weekly personal meetings, they kept in touch via email, Facebook, phone (it means smartphone in their case) and Google Site as well.

- Students had to create 5 written reports during the process (a Project Initiation Document, 3 status reports, and Final Documentation), which was uploaded to Moodle and evaluated there as well. 
However, in addition to making it easier for them to follow their own work, they also prepared a memo for each meeting (even more of them), that were attached to the final documentation. The team set their necessary inside communication plan with regard to linguistic diversity and the theme novelty.

\subsubsection{Device Usage and Teamwork from the Aspect of Gathering Information}

Gathering information seems as important as communication in the lifeline of the project.

- The first channel of information gathering was the Internet.

- On the next level came a narrow layer of the foreign community of UOD to expand the first version with useful comments and opinions. On this level, the questioning took place both face to face in the dormitory, school, and cafes and online as Messenger and Facebook shared questionnaire.

- On the third level, in addition to university peers, the website was tested with the members' acquaintances back at their home country (family, former high school peers, friends) to gather information to improve the finished product based on feedback received. The students were enthusiastic about the bugs, enjoyed the game, and many showed interest in both program development and design, it could say that the task has taken on an international dimension of its kind.

Successful mixing of the different work forms in the learning process is not unique among the students of higher education. According to a study of K. Erdélyi "At Óbuda University the best practice in international groups is that group activities and alone work take turns so each student gets the opprotunity to do in which he is the best." [31]

\subsubsection{The General Feedback of the Team Members}

At the end of the semester in time of project closure team members were asked to prepare a self-reflection of their own work. One part of this essay refered to the communication among the members with the following questions:

- With who did you communicate?

- When and how long did it take?

- How did it happen (what channel)?

- What kind of information did you exchange?

Normally all of them communicated with the whole team during the process. If their tasks connected to a certain team member's task, they had small chats only between them. 
The length of communication depended on the depth of the problem or the quiz of the next step. It took from 10 minutes long up to three and a half hours. The frequency of communication was various from occasional, through once in two weeks to every week or daily.

According to the way of communication, the student's answers were distributed equal proportions in roughly between face to face-and-online. The favored online form of communication was chat in Messenger, but Skype calls and emails were also very determinative.

The nature of the communication was discussion, information/content exchange, giving advice, giving a helping hand, problem-solving. Unfortunately not every team meeting was productive, as they looked back, they would change the frequency and organization of the communication.

Altogether all the members left the class with the same satisfying feeling as though they had a lack of their own preformance as they could not do everything like they expected, but the participation in the team was really good. The deadlines of work were respected by them, the team mates were all cooperative and comprehensive.

As the members reflected, they acquired a knowledge of several different subjects and developed some important skills such as: communication and negotiation, problem-solving, critical thinking, device and software usage and navigation among different platforms in the electronic environment.

Working on the project in general also helped them to develop such personal skills as planning, time managing, self-managing and relation building.

\section{Evaluation of the Results}

Within the basic statistical questions group, we asked the admission score and whether the respondent has high-school graduation in ICT field because personal motivation is an important factor in increasing success and efficiency. More than $50 \%$ of the respondents have a high-school education in IT (intermediate or advanced level or have taken a professional IT high-school education exam), but half of them did not remember the result of the admission, so the answer to this question greatly distorts the analysis, hence we could not draw conclusions.

One of the aims of our research in the tool use issue question group was to compare the use and frequency of using tools, thus exploring the spread of disruptive innovative technology. We found that $74 \%$ of both PC and laptop owners use their device at least once a day in the sample, and we found almost the same results with smartwatch owners (72\%). However, smartphones are used at least once a day by $96 \%$ of the sample. Less common devices are used less 
frequently by their owners: $12 \%$ of the sample said they use gamer consoles daily and $33 \%$ of the sample said they use drones weekly. We also found a surprising result in this issue: a student wearing VR glasses uses them every day.

When analysing the answers to the question about the source of knowledge, it became evident that the group of students in the current higher education needs collaboration, as more than $50 \%$ of the respondents often visit their social networking sites for information from their peers (55\%), other group members $(53 \%)$, acquaintances $(50 \%)$, and through various forums, including strangers $(36 \%)$.

Analysing the answers to the questions of the teamwork group, we also got an interesting result in the light of our previous findings, when the effectiveness was also examined. As an example, we investigated the grades of two courses of the semester 2017/18/2. The average subject grade in Informatics was 4.06 (with a negligible difference between the two courses). So, traditional, customized curriculum processing seems to be a completely appropriate method. Regarding the subject of Project Management and Practice, a very high average score was found (4.22), but here the part-time students did even better, their average was 4.58. The research did not explain the reasons for the difference; however, we assume that not only their high motivation level but also the greater practice working with peers could be the reason for the success.

We also examined students' perceptions of the advantages and disadvantages of teamwork. They had to mark the truthfulness of the various statements on a scale of 1 to 5 (with 5 as the best). The following results were obtained for the various statements about activities in the group:

- Possible benefits:

- More comfortable on the team then alone: 3.6;

- Easier, faster troubleshooting: 4.0;

- Easier and faster information retrieval: 3.5;

- Higher performance: 3.8 ;

- Values collective knowledge more than individually acquired knowledge: 3.0;

- The team is more active than working alone: 3.4.

Based on all of this, teamwork is preferred by respondents because of faster information acquisition and problem-solving as well as higher performance.

Examination of the willingness to engage in group and individual activities yielded an interesting result. It is hardly easier to get respondents to work if they can collaborate (3.3) than if they have to work individually (3.1). Since there is a very slight difference between the values, the question is why the previously stated (and more or less clearly evident) positive attributes did not add value to the motivation for cooperation. 
- Possible disadvantages:

- It is important not to adapt to others: 2.9;

- You can get deeper if you are alone: 3.6;

- Knowledge gained through individual activity is deeper: 3.4;

- It is more favored to work with machines rather than people: 2.9;

- They like organizing themselves and their activities: 3.9;

- The advantage of individual work is that it is free of conflict: 3.6;

- Work is more productive if you do not have to wait for others or to argue with others: 3.6 .

Thus, we can conclude that the need for independence and the avoidance of conflicts justify the need for an individual form of work solution.

It is clear from the students' answers that we, as educators, need to be open to innovative, disruptive technologies in order to keep up with their needs by delivering knowledge in a format that is favored by the $\mathrm{Y}$ and $\mathrm{Z}$ generations. And of course, they basically like to collaborate, to co-operate with each other, but that does not mean that this is the only "magic weapon" that is perfect in every situation. The right form of work should be well chosen in the given situation, subject and actors.

\section{Conclusions}

There are many factors that influence learning success. It depends on personal competences, the nature of the topic to be addressed, the learning environment, the available equipment, the applicable methodological repertoire and so on. The successful output is best assured when the priority between the influencing factors is designed according to the goal to be achieved. Rising above the traditional approach opens the door to a wide range of possibilities, both in a tangible realworld environment and in the virtual space, but can be fully utilized with healthy self-knowledge and appropriate prior knowledge.

Characteristics of today's learning society, such as the need for experiential learning that provides autonomy and flexibility, digital communication, openness to virtuality, the availability of instant information and constant online connectivity, the preference for small units that are easy to process and social activities, cooperation, and preference for collaboration also direct the individual learning process towards community space, community wealth, community experience, and collective knowledge. [33] [34] Students prefer subjects where they can work in teams, that is to say, rather than autocratic control, they are in an equal decision making position, but responsibility is shared. Beyond that; however, they get the autonomy they desire, as they individually perform the tasks that are appropriate to their role and that are most appropriate to their competencies. [35] 
Taking into account students' different personalities, as a member of a team, whether extroverted or introverted, the individual is capable of self-realization and development. Extroverted energy derives from social interactions in a cooperative, collaborative, supportive environment. Compared to the opinions of others, team spirit also contributes to the efficiency of their work in solving problems that they are capable of. The distribution of responsibility can be liberating, so the fear of possible failure is minimized, making the individual much more impulsive in problem-solving. [36]

Individual work in roles that match the personality traits within the team favors introverted personalities in depth. As they work on assignments that match their competencies, students can follow their own schedules to achieve the goal set by the team. Individual work within a team has the potential for productive work, which leads to the completion of successful subtask with its own time and energy, thereby creating a feeling of happiness for the individual. Not having to adapt to others can increase the efficiency of the work, but is also aware of the fact that you can count on the help of team members when they encounter a problem or a decision situation that gives their output a sense of uncertainty. [37]

\section{Acknowledgment}

This research was supported by EFOP-3.6.1-16-2016-00003 grants, Establishment long-term R \& D \& I process at the University of Dunaújváros.

\section{References}

[1] Hannah Dumont, Francisco Benavide, David Istance: The Nature of Learning: Using Research ot Inspire Practice, OECD Secretary-General, 2010

[2] Magyarország Kormánya: Digital Education Strategy (Magyarország Digitális Oktatási Stratégiája), Budapest, 2016.06.30.

[3] Diana Oblinger \& James L. Oblinger: Is It Age or IT: First Steps Toward Understanding the Net Generation, North Carolina State University, North Carolina, USA, 2012. október 24

[4] Csilla Mariann Szabó: Can The Gap between Digital Natives and Digital Immigrants be Bridged in Education? (Áthidalható-e a szakadék az oktatásban a digitális bennszülöttek és a digitális beválndorlók között?) In: Hulyák-Tomesz Tímea (2019. szerk): Generációs kérdések a kommunikációs készségfejlesztésben. Budapest, Hungaroox Kiadó, pp. 923

[5] Csilla Mariann Szabó: Do Schools Prepare Students for Changes Indicated by Technological Innovations? (Felkészíti-e az iskola a tanulókat a technológia innovációk okozta változásokra?) In: Varga Aranka, Andl Helga, Molnár-Kovács Zsófia (2019. szerk.): Neveléstudomány Horizontok és dialógusok, Absztraktkötet, MTA Pedagógiai Tudományos Bizottság PTE BTK Neveléstudományi Intézet Pécs, 2019, p. 549 
[6] Katalin Radnóti: What kind of teaching and assessment methods do teachers use in today's Hungarian school? (Milyen oktatási és értékelési módszereket alkalmaznak a pedagógusok a mai magyar iskolában?), Hidak a tantárgyak között, Budapest, Országos Közoktatási Intézet, 2006, pp. 131167

[7] János Ollé: Learning management: structural and methodological features of activity-oriented digital curriculum (Oktatásszervezés: a tevékenységközpontú digitális tananyag strukturális és módszertani sajátosságai), Iskolakultúra és környezetpedagógia, 2018, pp. 59-69

[8] Szilvia Tóth-Mózer, Dóra Lévai: Extend the educational process to online communities (Az oktatási és nevelési folyamat kiterjesztése online közösségi felületekre), Hungarian Educational Research Journal, Vol. 1, No. 1, 2011

[9] Ken Robinson, Lou. Aaronica: Creative schools (Kreatív iskolák. Az oktatás alulról szerveződő forradalmi átalakítása), Budapest: HVG Kiadó Zrt, 2018

[10] Mariann Váraljai: Establish innovative learning environment by virtual lab concept: An exploratory research in higher education, in $7^{\text {th }}$ IEEE International Conference on Cognitive Infocommunications (CogInfoCom), Wroclaw, Poland, 2016

[11] Tempus Közalapítvány: Learning environments (Tanulási környezetek), 10. 05. 2019 [Online] Available: https://tka.hu/celcsoport/6479/tanulasikornyezetek [date: 1008 2019]

[12] Bálint Nagy, Mariann Váraljai: A survey in issues of disruptive technologies to broaden learning for the future students, $10^{\text {th }}$ IEEE International Conference on Cognitive Infocommunications, 2019

[13] Peter Barrett, Yufan Zhang, Fay Davies, Lucinda Barrett: Clever Classrooms - Summary report of the HEAD Project," University of Salford, Manchester, 2015

[14] Attila Kovari: CogInfoCom Supported Education: A review of CogInfoCom based conference papers, Proceedings of the $9^{\text {th }}$ IEEE International Conference on Cognitive Infocommunications, 2018, pp. 233236

[15] I. Horváth: Evolution of teaching roles and tasks in VR / AR-based education, $9^{\text {th }}$ IEEE International Conference on Cognitive Infocommunications, Budapest, 2018, pp. 355-360

[16] Anna Sudár, Ádám B. Csapó: Interaction Patterns of Spatial Navigation in VR Workspaces, Proceedings of the $10^{\text {th }}$ IEEE International Conference on Cognitive Infocommunications, 2019, pp. 611-614 
[17] László Bognár, Éva Fáncsikné, Péter Horváth, Antal Joós, Bálint Nagy, Györgyi Strauber: Improved learning environment for calculus courses, Journal of Applied Technical and Educational Sciences, Vol. 8, No. 4, 2018, pp. 35-43

[18] Ilona Heldal, Carsten Helgesen: The Digital HealthLab: Supporting Interdisciplinary Projects in Engineering and in Health Education, Journal of Applied Technical and Educational Sciences, Vol. 8, No. 4, 2018, pp. 421

[19] Csaba Rigóczki, Andrei Damsa, Kristóf Györgyi-Ambró: Gamification on the edge of educational sciences and pedagogical methodologies, Journal of Applied Technical and Educational Sciences, Vol. 7, No. 4, 2017, pp. 79-88

[20] Robert Pinter, Sanja Maravic Cisar: Measuring Team Member Performance in Project Based Learning, Journal of Applied Technical and Educational Sciences, Vol. 8, No. 4, 2018, pp. 22-34

[21] Jozsef Katona, Attila Kovari: The Evaluation of BCI and PEBL-based Attention Tests, Acta Polytechnica Hungarica, Vol. 15, No. 3, 2018, pp. 225-249

[22] Gergely Sziladi, Tibor Ujbanyi, Jozsef Katona, Attila Kovari: The analysis of hand gesture based cursor position control during solve an IT related task, $8^{\text {th }}$ IEEE International Conference on Cognitive Infocommunications, 2017, pp. 413-418

[23] Costescu Cristina, Rosan Adrian, Nagy Brigitta, Heldal Ilona, Helgesen Carsten, Kővári Attila, Katona József, Thill Serge, Demeter Róbert, Efrem Igor: Assessing Visual Attention in Children Using GP3 Eye Tracker, Proceedings of the $10^{\text {th }}$ IEEE International Conference on Cognitive Infocommunications, 2019, pp. 343-348

[24] Tibor Ujbanyi, Gergely Sziladi, Jozsef Katona, Attila Kovari: ICT Based Interactive and Smart Technologies in Education-Teaching Difficulties. International Journal of Management and Applied Science, 2017, 3.10: 7277

[25] Elod Gogh, Attila Kovari: Metacognition and Lifelong Learning: A survey of secondary school students, $9^{\text {th }}$ IEEE International Conference on Cognitive Infocommunications, 2018, pp. 271-276

[26] Igor Fürstner, László Gogolák, and Peter Sarcevic: Development of telepresence technology during the teaching process at Subotica Tech, Journal of Applied Technical and Educational Sciences, Vol. 8, No. 4, 2018, pp. 44-53

[27] Elod Gogh, Attila Kovari: Examining the relationship between lifelong learning and language learning in a vocational training institution, Journal of Applied Technical and Educational Sciences, Vol. 8, No. 1, 2018, pp. $52-69$ 
[28] Ádám Merényi, Vince Szabó, Attila Takács: 101 ideas for innovative teachers, Budapest: Jedlik Oktatási Stúdió, 2006

[29] Naif M. Algashaam: Teamwork vs. Individual Responsibility, International Journal of Scientific and Engineering Research, Vol. 6, No. 10, pp. 286288,2015

[30] Judit Sántha és Tünde Polonyi: The digital natives and the school (A digitális bennszülöttek és az iskola) Debreceni Egyetemi Kiadó, Debrecen, 2017

[31] Krisztina Erdélyi: How Information Technology Helps to Mitigate Difficulties Occurred In: Teaching Intercultural Groups, ICETA $201210^{\text {th }}$ IEEE International Conference on Emerging eLearning Technologies and Applications, Stará Lesná, The High Tatras, Slovakia, November 8-9, 2012, p. 97

[32] Lajos Besenyei: The revolution of generation change (A generáció váltás forradalma), Opus et Educatio, Vol. 3, No. 4, p. 374

[33] Rita Ösz: Environment for problem solving in engineering higher education pp. 247-251, 5 p. In: Anikó, Szakál (szerk.) SISY 2015 : IEEE $13^{\text {th }}$ International Symposium on Intelligent Systems and Informatics : Proceedings New York, Amerikai Egyesült Államok : IEEE (2015) p. 329

[34] Paul A. Kirschner és Pedro De Bruyckere: The myths of the digital native and the multitasker, Teaching and Teacher Education, Vol. 67, 2017, pp. $135-142$

[35] Ghulam Mustafa, Richard Glavee-Geo és Paula M. Rice: Teamwork orientation and personal learning: The role of individual cultural values and value congruence, SA Journal of Industrial Psychology, 2017, pp. 1-13

[36] Pina Tarricone és Joseph Luca, Successful teamwork: A case study, Higher Education Research and Development Society of Australia - Annual Conference, Perth, Western Australia, 2002, pp. 640-646

[37] Jalal Hanasysha: Testing the Effects of Employee Empowerment, Teamwork, and Employee Training on Employee Productivity in Higher Education Sector, International Journal of Learning and Development, Macrothink Institute, Inc., 2016, pp. 164-178

[38] Peter Baranyi, Adam Csapo, Gyula Sallai, Cognitive Infocommunications (CogInfoCom), Springer International Publishing Switzerland, 2015, 219 p 